\title{
INSECTOPHONES IN THE ENGLISH PHONOSEMANTIC SYSTEM
}

\author{
V.V. Oschepkova, E.S. Razheva \\ Moscow Region State University \\ Radio st., 10a, Moscow, Russia, 105005 \\ razheva.elizaveta@rambler.ru
}

\begin{abstract}
The article is devoted the types of iconic lexis, the term insectophone is introduced and its place in the English phonosemantic system is defined. Insectophones differ from onomatopoeic words, vocatives, interjections, sound imitation words and ideophones. Insectophones take a specific niche in the phonosemantic system and can be regarded as a separate group of iconic lexis with its properties and functions.
\end{abstract}

Key words: insectophones, phonosemantic system, onomatopoeic words, vocatives, sound imitation, ideophonic words, phonetic motivation

\section{INTRODUCTION}

In the modern phonosemantic system there are several groups of iconic lexis. According to some scholars iconic lexis consists of words with a high emotional content and imagery. They include onomatopoeic words: giggle, sniff, twitter; interjections: achoo, ahem, bah; vocatives: Excuse me..., Sorry..., Pardon..., I beg your pardon..., and sound imitation words [Voronin 2009; Yusiphov 1986]. We single out one more special group of onomatopoeic words - insectophones.

\section{INSECTOPHONES}

The term insectophones is introduced to denote onomatopoeic names of insects, phonetic onomatopoeic insect signals, lexico-phonetic onomatopoeic words and lexical means of simulation of the acoustic signals of insects.

In this article there is undertaken an attempt to clarify the status of insectophones in the English phono-semantic system, to determine their properties and functions in the language and we try to determine the characteristics of this group of words, systematize them and compare them with the characteristics of onomatopoeic words, vocatives, intersections, sound imitation and ideophonic words.

English insectophones were selected by continuous sampling method from different dictionaries including etymology dictionaries, encyclopedias and British National Corpus: [ABBYY Lingvo.Pro.: https://www.lingvolive.com/ru-ru?lol=true\&utm_source= lingvo-online.ru\&utm_medium=301redirect\&utm_campaign=reg+landing]; Macmillan English Dictionary for Advanced Learners (2002); Oxford Advanced Learner's Dictionary of Current English (2004); Пятиязычный словарь названий животных (2000); Универсальный англо-русский словарь (2011); Encyclopedia of insects (2009); British National Corpus (2013). 
As a result, the group consists of 35 items: bee, beetle, bedbug, billbug, breeze, Boll Weevil, bombardier beetle, bug, bumble-bee, butterfly, buzz, caddisfly, carabus, chinch, click beetle, cockroach (roach), corn ground beetle, cricket, Daddy-long-legs, dragonfly, drone, Dumbledore, firefly, flea, fly, froghopper, gadfly, gnat, grasshopper (hopper), green-fly, hornet, horsefly, humble-bee, itch mite, katydid, mayfly, midge, midget, mosquito, moth, mozzie, sandfly, sawfly, scarab, scorpion, skeeter, spider, steam, sting, termite, tick, wasp, whistling moth.

\section{ENGLISH PHONO-SEMANTIC SYSTEM}

The status of insectophones is connected with the problem of distinguishing onomatopoeic words from other types of iconic lexis. Phono-semantic system of any language consists of iconic lexis. Iconic lexis can be divided into onomatopoeic words and sound symbolic words [Voronin 2009]. Onomatopoeia is defined as a phonetically motivated connection between word phonemes and a denotation which is the basics of sound naming. As for sound symbolism, it is a phenomenon which is a phonetically motivated connection between word phonemes and a denotation which is the basics of non-sound naming. According to onomatopoeia while pronouncing such a word a sound characteristic of denotation is observed. As we take into consideration sound symbolism in the word pronounced non-sound characteristic of denotation is shown.

In English iconic lexis the following word groups can be found: onomatopoeic words and sound symbolic words. Onomatopoeic words are items which produce sounds of the world around us with the help of phonemic means. In the foundation of naming of an onomatopoeic word there is sound. By the way the onomatopoeia is not understood as a direct naming of objects, phenomena, processes, but as an approximate naming of objects, phenomena, processes having a specific sound which then turns into the basic feature for naming such a word.

In the naming of a sound symbolic word a great set of characteristics can be used but not a sound. Moreover, we can say that the iconic language means include not only words which preserved their phonetic motivation but also words deprived of their direct phonetic motivation in the course of time but the connection between word phonemes and a denotation can be defined through etymological analysis. For example, one can include word bee into such a group. It has got an onomatopoeic origin. This word has developed many meanings: 'a meeting in a group where people combine work, competition and pleasure' [Oxford Advanced Learner's Dictionary of Current English 2004: 98] and 'a hard-working person' [Müller 2005: 62]. Besides, an idiom with this word the bee's knees means 'the best of the best of the society' [Oxford Advanced Learner's Dictionary of Current English 2004: 98].

\section{INSECTOPHONES AND IDEOPHONES}

Now let's consider each group of iconic lexis and compare it with insectophones. The term ideophone means 'a sound or sounds symbolizing a complete idea or spoken word, esp. sound symbolic words found in African languages' [Dictionary.com: $\mathrm{http} / /$ www.dictionary.com/browse/ideophone?s=ts]. So, one of the meanings of this term is used only for some African languages. On the other hand, ideophones are sound sym- 
bolic words [Linguistic Encyclopedic Dictionary: https://slovar.cc/rus/lingvist.html]. In psycholinguistics we can find two types of primary motivation - onomatopoeic words and ideophones. According to this classification ideophones stand for notation of quick motion, sparkling and also shape, size, distance and quality of objects. The distinguishing characteristics of such words are:

1) lack of connection with acoustic aspect of a language (Eng. totter 'go wrong walking; to shake', Khmer. mompe: m-mompoym 'to walk unsteadily', Lat. bulla 'water bubble', Indones. bulat 'round');

2) impossibility to refer ideophones to a word, morpheme or syllable. Ideophones represent fragments of words, parts of a root, as it can't attach to other morphemes. It is experimentally proved that the combination, which is composed of the same phonetic combination: bl-, kl-, fl-, gl-, pl-, sl - and br-, kr-, fr -, gr, spr-, str-, tr, has the same semantic characteristics. Sound combinations, which include phoneme /1/, are usually considered meaning 'small' and 'pleasant' (excluding gl-);

3) ideophones can be considered only as a part of a word, because one should have other sounds that make up a whole to understand their meaning. Fl- stands for light and fast movement. In order to understand the intensity and nature of this movement, it is necessary to refer to meaningful words, e.g., fly (the plane), flee (to disappear, to run, to fly), flow (water).

We believe that ideophones relate to the units of the second level of the phonosemantic system, i.e. sound symbolic system, and onomatopoeia - to the units of the first level.

\section{INSECTOPHONES AND SOUND IMITATION WORDS}

Insectophones are different from sound imitation words. Until recently there has been no clear distinction between imitation and onomatopoeia in the studies of imitative vocabulary. We share the point of view that onomatopoeic words shouldn't be mixed with sound imitation words. Currently the term onomatopoeia refers to the approximate transmission of the sound based on the inventory of phonemes of a given language, and the imitation - an accurate sound reproduction. As for insectophones they represent the approximate transmission of the insect sound. In commonly used sound imitation there are two types: 1) scientific simulation; 2) popular imitation [Yusiphov 1986: 7].

Popular imitation has been used by people for a very long time to send away, attract pets or cattle, for hunting purposes. Such an imitation should be as close to the standard sound to get the maximum result, because the success of human activity depends on this: shoo; kitty-kitty for a cat.

Scientific imitation is designed to portray most accurately and objectively the voices of birds, insects and animals for further study. For example, men use hunting calls to attract birds, to control the behavior of insects; scientists use a variety of devices that use ultrasound.

In everyday life imitation of sounds of domestic and wild animals is widely used. Such an imitation is more typical for spoken language. People do not use popular imitation of the sound of insects, because they are too difficult to imitate. Only scientific sound imitation is used. 


\section{INSECTOPHONES AND VOCATIVES}

Vocatives occupy a special place in the iconic lexis of the English language. Vocatives are understood as items referred to all proper names, phrases and nouns, used to refer to a human or an animal. There are two types of vocatives: 1) vocatives used for human beings: Excuse me, Sorry, Pardon..., I beg your pardon...; 2) vocative for animals and birds animals and birds: shoo; kitty-kitty.

The first type includes some proper names derived from the onomatopoeic names of insects, nicknames, particular nicknames in the network, based on the name of an insect, for example, Buzz-Buzz, or the nickname of the singer, Beyoncé - 'Bee'. We can say that the functions of vocatives and insectophones coincide in this case.

The words of sending away and attracting animals belong to the second type which is associated with onomatopoeia. People are not in such a close contact with the worlds of insects then with the world of animals and birds, so we can say that there are no insectophones in this type of vocabulary.

\section{INSECTOPHONES AND INTERJECTIONS}

Now let's compare onomatopoeic words (insectophones) and interjections. We share the point of view that they are absolutely different categories of words.

The study still shows that onomatopoeic words (insectophones) and interjections have some common features:

1) both interjections and insectophones are purely intonation categories. They both transmit sounds approximately: ha-ha, oops, oh, blah;

2) unusual phonetic elements are preserved in interjections and in insectophones. For example, in the insectophone buzz we can find doubling of the fricative sound; in English, there is an unusual word ending with the letter $\mathbf{h}: b a h, o h, a h$ or doubling up $\mathrm{o}$ at the beginning of words: oops, oomph;

3 ) interjections and insectophones arethe productive basis for word formation. The most productive way of word formation in the English language is the conversion, so the word does not change the external form, it changes the meaning. The word blah as a noun has the following meanings: a) nonsense: blah to talk - to talk nonsense; b) melancholy, bad mood: He told me he just had a case of the blahs. The same word as an adjective can mean: a) boring, uninteresting, and dull: a blah winter day - dreary winter day; b) depressed, sad, feeling unwell: to wake up in a blah mood - to wake up in a bad mood. New words develop on the basis of phonetically signals of insects. The word $b u z z(\mathrm{v})$ developed the following meanings: a) to mumble, to speak indistinctly; b) to make a fuss; c) to gossip, to whisper; d) to call; e) to cut short; f) to sawwith a circular saw; g) slang. to fly low-level flight; h) to throw; i) to drink to the bottom (the bottle); j) empty smb's pockets. Buzz (n) (insects): a) coll. phone call; b) a horn, siren, buzzer; c) coll. the buzz from alcohol or drug intoxication, state of overstimulation; d) ling. a ringing noise, accompanied by the recitation of the sonorous sounds; e) whim, crotchet; f) buzz-bomb (n) 'aircraft projectile'; g) the buzz-saw (Am.) 'circular saw' [ABBYY Lingvo.Pro.: https://www.lingvolive.com/ru-ru/translate/en-ru/buzz]; 
4) the category of both words retain direct nominative meaning: interjection: phew, shoo; insectophones have a primary motivation: bug, bee, beetle;

5) interjections and onomatopoeic words are the key components of two theories of the origin of language: interjection and onomatopoeic.

At the same time insectophones and interjections differ:

1) unlike insectophones, interjections express the feeling, but don't name it, so in the dictionary next to the interjections there are notes explaining the emotion, e.g., grief, bewilderment, joy. Unlike interjections, insectophones have a very specific meaning and require no additional explanation: bee 'a black and yellow flying insect that stings' [Oxford Advanced Learner's Dictionary of Current English 2004: 98];

2) insectophones have a specific lexical meaning: beetle 'an insect, often large and black, with a hard case on its back covering its wings' [Oxford Advanced Learner's Dictionary of Current English 2004: 98]. Interjections can convey a variety of hues of emotions, but do not have a specific lexical meaning, for instance, wow is used to express great surprise and admiration [Oxford Advanced Learner's Dictionary of Current English 2004: 1497];

3) intonation, phonetic features, facial and gestural support (passed in the written text of the author's remarks) are an integral part of a semantic system for interjections. For example: "Ah, but how do you know that you would?" said Uncle Andrew with a cunning smile [Lewis 2008: 16];

Moreover, interjections can be omitted in sentences without changing the meaning:

4) unlike interjections that do not have grammatical meanings, as they do not have a system of grammatical forms and, therefore they are neither auxiliary parts of speech nor meaningful words. Insectophones can act as different parts of the sentence - subject, predicate, object. Consider the following examples. Shall I give him a buzz? (object). A bee buzzed through the hall (predicate);

5) interjections have no inflection forms, while insectophones have them. In English conversion is very often used: to buzz (v) - a buzz (n).

\section{CLASSIFICATION OF ONOMATOPOEIC WORDS AND THE PLACE OF INSECTOPHONES IN THIS SYSTEM}

We offer the following classification of onomatopoeic words according to their origin:

1) Onomatopoeic words based on sounds of the anthropomorphic and zoomorphic world:

- based on the sounds produced by humans: cough, giggle, whistle, hiccup;

- animal sounds: woof-woof, moo, miow;

— the sounds of birds and bird names: twitter, cuckoo, chirp, chirp;

— the sounds of insects, names of insects (insectophones): buzz, bug, beetle, bee;

— the sounds of reptiles: hiss.

2) Onomatopoeic words based on the sounds of an inanimate nature:

— the sounds of nature: the sound of falling drops — drip, drop; the sound of water, river - bubble, gurgle, slush;

— the sounds produced by plants and trees: rustle. 
3) Onomatopoeic words based on the sounds of a variety of human devices, and the movements produced by the person and these devices:

- sounds generated by technical devices: lock, tick-tack, ring;

- sounds of musical instruments: clang, thrum, drum, horn;

- noises arising from movement: creak, rustle.

The lexical-semantic subgroup of insectophones is included into the group of zoophones, e.g., woof-woof; cucoo. The elements of this subgroup differ from other items by their origin - onomatopoeic insects names and sounds they produce.

\section{THE USAGE OF INSECTOPHONES}

Insectophones are used in a scientific literature; they are parts of terminology systems. Besides they can be the source of making idioms: to have a bee in one's bonnet; a busy bee; be the bee's knees; blind as a bee; lively (merry) as a cricket; chirpy as a cricket; it isn't cricket [Macmillan English Dictionary 2014]. Insectophones can be metaphorical descriptions which refer to men. In English cricket is associated with a merry and happy person.

\section{CONCLUSION}

The analysis proves that insectophones occupy a special niche in a phono-semantic system of the English language. They can be regarded as one of the groups of iconic lexis together along with onomatopoeic words, vocatives, interjections, sound imitation words and ideophones. Insectophones perform the same functions as other groups of iconic lexis. Insectophones are more often used in idioms and in terminology than onomatopoeic words.

(C) Ощепкова В.В., Ряжева Е.С. Дата поступления: 18.08.2016. Дата принятия: 22.10.2016

\section{BIBLIOGRAPHIC LIST}

1. Воронин C.B. (2009). Основы фоносемантики [Voronin S.V. The basics of phonosemantics]. Москва: Ленанд.

2. Лингвистический энциклопедический словарь (1990). Москва: Советская энциклопедия: https://slovar.cc/rus/lingvist.html (09.10.2016).

3. Мюллер B.K. (2005). Новый англо-русский словарь [Müller V.K. Modern English-Russian Dictionary]. Москва: Русский язык-Медиа.

4. Юсифов Н.М. (1986). Лексико-семантические особенности английских звукоподражательных слов [Yusiphov N.M. Lexical-semantic features of English onomatopoeic words]: Дисс. ... канд. филол. наук: Пятигорск.

5. ABBYY Lingvo.Pro: https://www.lingvolive.com/ru-ru?lol=true\&utm_source=lingvo-online.ru\& utm_medium=301redirect\&utm_campaign=reg+landing $(09.10 .201 \overline{6})$.

6. British National Corpus: http: //corpus.byu.edu/bnc (01.09.2016).

7. Dictionary.com: http://www.dictionary.com/browse/ideophone?s=ts (05.09.2016).

8. Lewis C.S. (2008). The chronicles of Narnia. Harper Collins Publishers.

9. Macmillan English Dictionary for Advanced Learners (2002). Macmillan Publishers Limited.

10. Oxford Advanced Learner's Dictionary of Current English (2004). Oxford University Press. 
УДК: 81'37:81'34

DOI: 10.22363/2313-2299-2017-8-1-188-194

\title{
ИНСЕКТОФОНЫ В ФОНОСЕМАНТИЧЕСКОЙ СИСТЕМЕ АНГЛИЙСКОГО ЯЗЫКА
}

\author{
В.В. Ощепкова, Е.С. Ражева \\ Московский государственный областной университет \\ ул. Радио, 10 а, Москва, Россия, 105005 \\ razheva.elizaveta@rambler.ru
}

\begin{abstract}
В статье рассматриваются типы звукоизобразительной лексики. Авторами вводится в научный оборот термин «инсектофон» и определяется его место в фоносемантической системе английского языка. Инсектофоны следует отличать от звукоподражательных слов, вокативов, междометий, имитативов и идеофонов. Инсектофоны занимают определенную нишу в фоносемантической системе и могут рассматриваться в качестве отдельной группы в составе звукоизобразительной лексики, обладая собственными свойствами и функциями.
\end{abstract}

Ключевые слова: инсектофоны, фоносемантическая система, звукоподразательные слова, вокативы, имитативы, идеофоны, фонетическая мотивированность 